\title{
Pengaruh Asupan Nutrisi Shake Kacang Kedelai terhadap Skala Lemak Perut Guru-guru Sekolah Dasar di Bangkinang Kota Kabupaten Kampar
}

\author{
Ramdhan Witarsa $^{1}$, Fadhilaturrahmi $^{2}$, Muhammad Syahrul Rizal $^{3}$ \\ Universitas Pahlawan Tuanku Tambusai, Riau, Indonesia ${ }^{1,2,3}$ \\ E-mail : $\underline{\text { drdadan19@gmail.com }}{ }^{1} \underline{\text { arkhan88fadhila@gmail.com }{ }^{2}} \underline{\text { syahrul.rizal92@gmail.com }{ }^{3}}$
}

\begin{abstract}
Abstrak
Permasalahan penelitian yang melatarbelakangi penelitian ini adalah banyaknya guru-guru sekolah dasar yang memiliki kelebihan berat badan dan perut yang buncit. Hal ini dikarenakan skala lemak perut tinggi yang dimiliki hampir sebagian besar guru-guru sekolah dasar di Bangkinang Kota, Kabupaten Kampar. Tingginya skala lemak perut tersebut dikarenakan kurangnya olahraga dan asupan nutrisi yang salah. Tujuan penelitian ini ingin melihat pengaruh asupan nutrisi shake kacang kedelai yang dipercaya sebagai rendah kalori namun berenergi tinggi terhadap skala lemak perut guru-guru. Metode penelitian yang digunakan adalah kuasi eksperimen. Jumlah sampel sebanyak 20 orang guru. Hasil penelitian menunjukkan bahwa dengan pemberian asupan nutrisi shake kacang kedelai selama satu bulan secara signifikan menurunkan skala lemak perut dari kategori bahaya ke kategori tinggi $(80 \%)$ dan semakin bugarnya fisik guru-guru yang diteliti. Kebaruan penelitian ini adalah adanya peningkatan skala kesehatan guru-guru serta cara dan gaya hidup sehat. Dampak dan impak dari hasil penelitian ini adalah cara dan gaya hidup sehat yang dijalanin selama program dilanjutkan oleh guru-guru tersebut di lingkungan kelas dan lingkungan keluarganya.
\end{abstract}

Kata kunci: nutrisi, shake, kacang kedelai, skala, lemak perut, guru, sekolah dasar

\section{Abstract}

The research problem underlying this study is the large number of elementary school teachers who are overweight and have a distended stomach. This is because the scale of high belly fat possessed by most of the elementary school teachers in Bangkinang Kota, Kampar Regency. The high belly fat scale is due to lack of exercise and incorrect nutrition. The purpose of this study is to look at the effect of soybean shake nutrition intake which is believed to be low in calories but high in energy on the belly fat scale of teachers. The research method used was quasi-experimental. The total sample of 20 teachers. The results showed that by providing nutritional intake of soybean shakes for one month significantly reduced the scale of abdominal fat from the hazard category to the high category (80\%) and the increasingly physical bugs of the teachers studied. The novelty of this research is that there is an increase in the scale of teachers' health and ways and healthy lifestyles. The impact and impact of the results of this study are the ways and healthy lifestyles that are carried out during the program continued by the teachers in the classroom and family environment.

Keywords: nutrition, shake, soybeans, scale, belly fat, teacher, elementary school

Copyright (c) 2020 Ramdhan Witarsa, Fadhilaturrahmi, Muhammad Syahrul Rizal

$\triangle$ Corresponding author :

Address : Jalan Tuanku Tambusai No.23

Email : drdadan19@gmail.com

Phone : 081221568012

ISSN 2580-3735 (Media Cetak)

ISSN 2580-1147 (Media Online)

DOI: https://doi.org/10.31004/basicedu.v4i4.506 
1115 Pengaruh Asupan Nutrisi Shake Kacang Kedelai terhadap Skala Lemak Perut Guru-guru Sekolah Dasar di Bangkinang Kota Kabupaten Kampar - Ramdhan Witarsa, Fadhilaturrahmi, Muhammad Syahrul Rizal

DOI: https://doi.org/10.31004/basicedu.v4i4.506

\section{PENDAHULUAN}

Permasalahan penelitian yang melatarbelakangi penelitian ini adalah banyaknya guruguru sekolah dasar (SD) yang memiliki kelebihan berat badan dan perut yang buncit. Hal ini disinyalir dikarenakan skala lemak perut yang tinggi yang dimiliki hampir sebagian besar guruguru SD di Bangkinang Kota, Kabupaten Kampar. Tingginya skala lemak perut pada guru-guru SD tersebut disinyalir dikarenakan kurangnya bergerak/berolahraga dan dikarenakan asupan nutrisi yang salah dan tinggi akan kalori (Rahardjo, Bahar, \& Adi, 2019).

Dengan kondisi demikian, maka timbulah ide rencana untuk memberikan asupan nutrisi shake kacang kedelai untuk menurunkan skala lemak perut guru-guru SD tersebut agar lebih sehat dan bugar. Asupan shake kacang kedelai yang memiliki jumlah kalori rendah dipercaya dapat membantu guru-guru SD agar lebih sehat dan bugar serta memiliki perut yang ramping (Krisnawati, 2017).

Tujuan penelitian ini ingin melihat pengaruh asupan nutrisi shake kacang kedelai yang dipercaya sebagai rendah kalori namun berenergi tinggi terhadap skala lemak perut guru-guru SD. Dengan program pemberian asupan nutrisi selama satu bulan ini, peneliti ingin melihat ketercapaian penurunan skala lemak perut yang berpengaruh juga terhadap skala kesehatan pada setiap guru yang diteliti (Utami, Majid, \& Herawati, 2017).

Secara teoritik, berbagai strategi perawatan dan penurunan berat badan yang tersedia sudah beberapa kali dicoba oleh guru-guru, namun hasilnya tidak maksimal. Dalam penelitian ini, selain asupan shake kacang kedelai yang diberikan, diberikan juga perlakuan penambahan aktivitas fisik seperti berjalan kaki 30 menit dan modifikasi perilaku saat jam istirahat dengan mengubah menu camilan menjadi buah-buahan dan sayuran (Fatimah, Dieny, Murbawani, Fahmy, \& Tsani, 2018).

Hanya $20 \%$ individu yang kelebihan berat badan kehilangan berat badan berhasil untuk pemeliharaan berat badan apabila didefinisikan sebagai kehilangan berat badan setidaknya $10 \%$ dari berat badan awal dan mempertahankannya setidaknya selama satu tahun. Dengan demikian, strategi ditingkatkan untuk mencegah penambahan berat kembali diperlukan (Fatimah et al., 2018).

Saat ini, diet rendah karbohidrat dan protein lebih tinggi telah menunjukkan harapan untuk penurunan berat badan jika dibandingkan untuk mengurangi energi dan diet lemak. Secara khusus, beberapa penelitian menunjukkan bahwa diet rendah karbohidrat mungkin menghasilkan penurunan berat badan yang lebih besar daripada diet rendah lemak tradisional lebih dari enam bulan dan mungkin sebanding dengan diet rendah lemak lebih dari 12 bulan. Meskipun ada bukti yang mendukung bahwa diet rendah karbohidrat sebagai alat yang efektif untuk menurunkan berat badan dan efeknya untuk pemeliharaan berat badan tidak jelas (Jati, 2014).

Oleh karena itu, tujuan dari penelitian ini adalah untuk membandingkan skala lemak perut sebelum dan sesudah pemberian asupan nutrisi shake kacang kedelai pada guru/orang dewasa 
1116 Pengaruh Asupan Nutrisi Shake Kacang Kedelai terhadap Skala Lemak Perut Guru-guru Sekolah Dasar di Bangkinang Kota Kabupaten Kampar - Ramdhan Witarsa, Fadhilaturrahmi, Muhammad Syahrul Rizal

DOI: https://doi.org/10.31004/basicedu.v4i4.506

selama satu bulan. Skala lemak perut sebelum perlakuan diukur melalui timbangan digital Tanita untuk mengukur komposisi tubuh mereka secara lengkap. Melalui timbangan digital Tanita tersebut bisa diketahui komposisi tubuh setiap orang sebagai berikut: berat badan, lemak tubuh, kadar air, massa otot, rating fisik, kalori, usia sel, massa tulang, dan lemak perut.

Berat badan secara ideal itu bergantung dari jenis kelamin. Apabila perempuan, berat badan ideal dihitung dengan cara mengurangi tinggi badan dikurangi 110, sedangkan untuk laki-laki dikurangi 100. Misalnya tinggi badan seorang perempuan $165 \mathrm{~cm}$, maka berat badan idealnya seharusnya 55 kg (165-110). Berbeda dengan lakilaki, pengurangannya dikurangi 100. Misalnya tinggi badan seorang laki-laki $170 \mathrm{~cm}$, maka berat badan idealnya $70 \mathrm{~kg}$ (170-100).

Lemak tubuh merupakan lemak yang terdapat di bagian-bagian tubuh seperti di tangan, paha, dan pinggul. Lemak tubuh bisa diketahui melalui timbangan digital Tanita juga. Untuk ukuran lemak tubuhnya digambarkan sebagai berikut:

Tabel 1. Ukuran Lemak Tubuh

\begin{tabular}{|l|c|c|}
\hline Jenis Kelamin & $\begin{array}{c}\text { Usia di Bawah } \\
30 \text { tahun (\%) }\end{array}$ & $\begin{array}{c}\text { Usia di Atas } \\
30 \text { tahun (\%) }\end{array}$ \\
\hline Pria & $14-20$ & $17-23$ \\
\hline Wanita & $17-24$ & $20-27$ \\
\hline
\end{tabular}

Ukuran kadar air dalam tubuh menunjukkan seberapa besar kandungan air yang ada di tubuh seseorang. Semakin banyak kadar air pada tubuh seseorang, maka akan semakin sehat (Amanto,
Siswanti, \& Atmaja, 2015). Ukuran kadar air seseorang dalam tubuh digambarkan sebagai berikut:

Tabel 2. Kadar Air

\begin{tabular}{|c|c|}
\hline Jenis Kelamin & Kadar Air (\%) \\
\hline Wanita & $50-55$ \\
\hline Pria & $60-65$ \\
\hline
\end{tabular}

(Sumber: (Prasetyo, Isdiana, \& Sujadi, 2019).

Massa Otot memiliki ukuran 1-9. Massa otot ini akan berhubungan dengan rating fisik yang dimiliki seseorang. Berikut penilaiannya:

Tabel 3. Rating Fisik

\begin{tabular}{|c|c|}
\hline Rating Fisik & Keterangan \\
\hline 1 & Obesitas tersembunyi \\
\hline 2 & Obesitas \\
\hline 3 & Gemuk \\
\hline 4 & Kurang berotot \\
\hline 5 & Standar normal \\
\hline 6 & Berotot (atlit) \\
\hline 7 & Kurus \\
\hline 8 & $\begin{array}{c}\text { Kurus berotot } \\
\text { berotot }\end{array}$ \\
\hline 9 & \\
\hline
\end{tabular}

Kalori merupakan jumlah asupan yang dibutuhkan dalam tubuh. Jumlah kalori ini akan memberi tahu kepada seseorang seberapa besar jumlah kalori yang dibutuhkan oleh seseorang. Asupan kalori seseorang berbeda setiap orangnya. Dengan kita mengetahui berapa asupan kalori yang dibutuhkan oleh seseorang, maka kita akan mengetahui program apa yang dibutuhkan oleh seseorang tersebut. Apakah harus langsing dan menurunkan berat badan, apakah hanya untuk 
1117 Pengaruh Asupan Nutrisi Shake Kacang Kedelai terhadap Skala Lemak Perut Guru-guru Sekolah Dasar di Bangkinang Kota Kabupaten Kampar - Ramdhan Witarsa, Fadhilaturrahmi, Muhammad Syahrul Rizal

DOI: https://doi.org/10.31004/basicedu.v4i4.506

sehat dan memenuhi asupan kalori saja, atau justru harus gemuk (Jati, 2014).

Usia sel akan menunjukan seberapa besar usia sel kita dibandingkan dengan usia kita sesungguhnya. Ukuran usia sel ini akan menunjukan apakah usia sel yang kita miliki lebih besar, lebih kecil, atau justru sama dengan usia kita sesungguhnya. Ini akan memberikan peringatan ke kita tentang kesehatan kita dan kesehatan metabolisme tubuh seseorang.

Massa tulang akan menunjukkan ukuran seberapa besar kandungan kalsium yang ada dalam tulang dan tubuh kita. Massa tulang ini dibutuhkan berdasarkan berat badan yang kita miliki. Berikut gambarannya:

Tabel 4. Massa Tulang untuk Wanita

\begin{tabular}{|c|c|c|}
\hline $\begin{array}{c}\text { BB kurang } \\
\text { dari } 50 \mathrm{~kg}\end{array}$ & $\begin{array}{c}\text { BB } 50 \mathrm{~kg}-70 \\
\mathrm{~kg}\end{array}$ & $\begin{array}{c}\text { BB lebih dari } \\
70 \mathrm{~kg}\end{array}$ \\
\hline 1,95 & 2,40 & 2,95 \\
\hline
\end{tabular}

Massa tulang untuk pria digambarkan sebagai berikut:

Tabel 5. Massa Tulang untuk Pria

\begin{tabular}{|c|c|c|}
\hline $\begin{array}{c}\text { BB kurang } \\
\text { dari } 65 \mathrm{~kg}\end{array}$ & $\begin{array}{c}\text { BB } 65 \mathrm{~kg}-95 \\
\mathrm{~kg}\end{array}$ & $\begin{array}{c}\text { BB lebih dari } \\
95 \mathrm{~kg}\end{array}$ \\
\hline 1,95 & 2,40 & 2,95 \\
\hline
\end{tabular}

Lemak perut merupakan lemak yang ada di perut. Inilah yang menyebabkan buncitnya seseorang dan merupakan sumber segala penyakit. Adapun skala lemak perut digambarkan sebagai berikut:
Tabel 6. Lemak Perut

\begin{tabular}{|c|c|}
\hline Skala & Kategori \\
\hline $1-5$ & Sehat Ideal \\
\hline $6-9$ & Tinggi \\
\hline $10-14$ & Bahaya \\
\hline $15-59$ & Sangat Bahaya \\
\hline
\end{tabular}

Skala 1 - 5 dapat dikatakan lemak perut dalam batas sehat ideal, terus lakukan monitoring agar skala lemak perut sehat ideal ini tidak beranjak ke skala 6 keatas/kategori tinggi. Skala 6 - 9 dapat dikatakan lemak perut cukup tinggi, tetapi masih merasa sehat, perlu waspada dan harus dikurangi dengan menurunkan berat badan dan lemak perutnya. Apabila tidak dikontrol, penambahan skala lemak perut ini cepat bertambahnya dikarenakan pola makan yang semakin buruk (Samaha, 2003).

Skala 10 - 14 dapat dikatakan skala lemak perut tinggi dan bahaya. Skala ini diluar kisaran batasan sehat. Jika dibiarkan akan beresiko terhadap penyakit-penyakit degeneratif seperti diabetes, kanker, tekanan darah tinggi, jantung, dan penyakit-penyakit lainnya.

Skala 15 - 59 dapat dikatakan skala lemak perut sangat bahaya. Pada skala ini tidak ada alasan untuk menunda apabila ingin menghabiskan sisa usia dengan sehat dan bugar. Ingat, penyakit degeneratif merupakan penyakit akibat kemunduran fungsi organ tubuh, pemulihannya memerlukan waktu, biaya pengobatannya mahal, dan perbaikan gaya hidup sehat sebelumnya sulit, serta kabar buruknya adalah sebagian besar tidak dapat pulih ke kondisi kesehatan seperti sedia kala. 
1118 Pengaruh Asupan Nutrisi Shake Kacang Kedelai terhadap Skala Lemak Perut Guru-guru Sekolah Dasar di Bangkinang Kota Kabupaten Kampar - Ramdhan Witarsa, Fadhilaturrahmi, Muhammad Syahrul Rizal

DOI: https://doi.org/10.31004/basicedu.v4i4.506

Mencegah lebih baik daripada mengobati (Yancy, 2004).

Hasil penelitian ini diharapkan dapat menurunkan skala lemak perut guru-guru lewat asupan nutrisi shake kacang kedelai sehingga guru-guru semakin sehat dan fit saat menjalankan aktivitas hariannya di sekolah. Manfaat penelitian ini diharapkan memberikan manfaat semakin bertambahnya pengetahuan guru-guru akan asupan nutrisi yang baik serta pengetahuan baru tentang cara dan gaya hidup sehat yang bisa diaplikasikan pada diri sendiri dan keluarganya di rumah.

\section{METODE}

Penelitian ini dilakukan dalam konteks manajemen berat badan sebelum dan sesudah program pemberian asupan nutrisi shake kacang kedelai kepada guru-guru Sekolah Dasar (SD). Semua peserta penelitian menerima asupan nutrisi shake kacang kedelai selama satu bulan untuk diet penurunan berat badan yang ditunjukkan dalam skala lemak perut yang diukur menggunakan timbangan Tanita diikuti dengan diet pemeliharaan berat badan selama satu bulan baik rendah karbohidrat dan lemak.

Desain penelitiannya menggunakan kuasi eksperimen dengan mengukur skala lemak perut sebelum dan sesudah pemberian asupan nutrisi shake kacang kedelai. Jumlah peserta sebanyak 20 guru. Setiap guru dianalisis hasil programnya masing-masing berdasarkan tabel monitoring komposisi tubuh. Rancangan desain penelitiannya menggunakan rancangan kuasi eksperimen pre- post test menggunakan satu kelompok (Rahardjo et al., 2019)

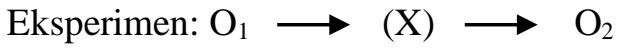

Gambar . Desain Penelitian

Keterangan:

$\mathrm{O}_{1}=$ kondisi guru-guru SD sebelum perlakuan.

$\mathrm{X}=$ pemberian asupan nutrisi shake kacang kedelai selama satu bulan.

$\mathrm{O}_{2}=$ kondisi guru-guru SD setelah perlakuan.

Peserta atau sampel dalam penelitian ini adalah guru-guru SD yang ada di Bangkinang Kota, Kabupaten Kampar. Penelitian ini disetujui oleh Kepala-kepala Sekolah di masing-masing SD. Peserta yang mengikuti program ini disediakan oleh setiap Kepala Sekolah dan direkrut melalui informasi yang diberikan saat rapat guru.

Peserta penelitian ini merupakan orang dewasa (guru) yang sehat, berusia 24 hingga 50 tahun, yang sebelumnya tidak banyak bergerak, memiliki perut buncit, dan kelebihan berat badan. Guru-guru tersebut tidak merokok, tidak sedang diet khusus, dapat berolahraga, tidak hamil, dan tidak sedang menyusui.

Sebelum berpartisipasi dalam program penelitian ini, mereka dievaluasi terlebih dahulu menggunakan timbangan Tanita untuk diketahui komposisi tubuhnya masing-masing. Melalui timbangan Tanita ini dapat diketahui hal-hal sebagai yang terlihat pada Tabel 7 . 
1119 Pengaruh Asupan Nutrisi Shake Kacang Kedelai terhadap Skala Lemak Perut Guru-guru Sekolah Dasar di Bangkinang Kota Kabupaten Kampar - Ramdhan Witarsa, Fadhilaturrahmi, Muhammad Syahrul Rizal

DOI: https://doi.org/10.31004/basicedu.v4i4.506

Tabel 7. Komposisi Tubuh yang Bisa Terukur melalui Timbangan Tanita

\begin{tabular}{|c|l|}
\hline No. & \multicolumn{1}{|c|}{ Komposisi Tubuh } \\
\hline 1 & Berat badan \\
\hline 2 & Lemak tubuh \\
\hline 3 & Kadar air \\
\hline 4 & Massa otot \\
\hline 5 & Rating fisik \\
\hline 6 & Kalori \\
\hline 7 & Usia sel \\
\hline 8 & Massa tulang \\
\hline 9 & Lemak perut \\
\hline
\end{tabular}

Tabel 8. Komposisi Tubuh Guru-guru SD sebelum Perlakuan

\begin{tabular}{|c|c|c|c|c|c|c|c|c|c|c|}
\hline No. & Kode Guru & 1 & 2 & 3 & 4 & 5 & 6 & 7 & 8 & 9 \\
\hline 1 & G1 & 75 & 32 & 45 & 31 & 2 & 1400 & 55 & 1,8 & 9 \\
\hline 2 & G2 & 78 & 34 & 46 & 33 & 3 & 1276 & 60 & 1,5 & 9 \\
\hline 3 & G3 & 80 & 37 & 45 & 32 & 2 & 1346 & 57 & 1,6 & 10 \\
\hline 4 & G4 & 82 & 33 & 47 & 31 & 2 & 1443 & 58 & 1,7 & 12 \\
\hline 5 & G5 & 75 & 35 & 45 & 30 & 3 & 1447 & 55 & 1,8 & 14 \\
\hline 6 & G6 & 77 & 36 & 45 & 30 & 3 & 1446 & 60 & 1,2 & 15 \\
\hline 7 & G7 & 81 & 33 & 45 & 31 & 3 & 1110 & 57 & 1,3 & 10 \\
\hline 8 & G8 & 73 & 32 & 48 & 31 & 3 & 1265 & 57 & 1,6 & 11 \\
\hline 9 & G9 & 75 & 34 & 45 & 32 & 2 & 1256 & 56 & 1,7 & 12 \\
\hline 10 & G10 & 78 & 33 & 46 & 32 & 3 & 1367 & 67 & 1,2 & 14 \\
\hline 11 & G11 & 80 & 35 & 45 & 33 & 2 & 1567 & 67 & 1,5 & 13 \\
\hline 12 & G12 & 84 & 36 & 47 & 34 & 3 & 1492 & 60 & 1,6 & 9 \\
\hline 13 & G13 & 76 & 37 & 45 & 35 & 2 & 1246 & 67 & 1,7 & 10 \\
\hline 14 & G14 & 78 & 35 & 48 & 33 & 3 & 1289 & 60 & 1,8 & 9 \\
\hline 15 & G15 & 85 & 34 & 45 & 31 & 3 & 1231 & 65 & 1,5 & 8 \\
\hline 16 & G16 & 82 & 33 & 49 & 32 & 2 & 1222 & 50 & 1,6 & 7 \\
\hline 17 & G17 & 80 & 37 & 45 & 32 & 2 & 1346 & 57 & 1,6 & 10 \\
\hline 18 & G18 & 82 & 33 & 47 & 31 & 2 & 1443 & 58 & 1,7 & 12 \\
\hline 19 & G19 & 75 & 35 & 45 & 30 & 3 & 1447 & 55 & 1,8 & 14 \\
\hline 20 & G20 & 77 & 36 & 45 & 30 & 3 & 1446 & 60 & 1,2 & 15 \\
\hline
\end{tabular}

Keterangan:

1. Berat badan

3. Kadar air

5. Rating fisik

7. Usia sel

9. Lemak perut

2. Lemak tubuh

4. Massa otot

6. Kalori

8. Massa tulang

\section{HASIL DAN PEMBAHASAN}

Komposisi tubuh guru-guru Sekolah Dasar (SD) sebelum pemberian asupan nutrisi shake kacang kedelai dapat dilihat pada Tabel 8.
Dapat dilihat pada Tabel 8, komposisi Tubuh Guru-guru SD sebelum diberi perlakuan, perbandingan tinggi badan dan berat badan yang dimiliki setiap guru sudah tampak jelas bahwa 
1120 Pengaruh Asupan Nutrisi Shake Kacang Kedelai terhadap Skala Lemak Perut Guru-guru Sekolah Dasar di Bangkinang Kota Kabupaten Kampar - Ramdhan Witarsa, Fadhilaturrahmi, Muhammad Syahrul Rizal

DOI: https://doi.org/10.31004/basicedu.v4i4.506

semua guru memiliki komposisi tinggi badan dan berat badan yang tidak ideal.

Dari 20 orang guru SD yang diteliti, ke-20 nya (G1 - G20) memiliki kelebihan berat badan antara 5-10 kg per individunya. Rata-rata mereka memiliki kebiasaan sarapan dengan jumlah kalori yang besar. Kelebihan berat badan ini tentu saja relevan dengan lemak tubuh yang dimiliki guru. Ke-20 orang guru memiliki lemak tubuh diatas rata-rata yang seharusnya dibawah $30 \%$ (Krisnawati, 2017).

Berdasarkan tabel tersebut dapat dilihat juga kadar air yang dimiliki setiap guru. Keseluruhan guru tidak memiliki kadar air yang seharusnya diatas 50\% (Yuarni, Kadirman, \& Jamaluddin, 2018). Ke-20 orang guru tersebut kurang minum air bening dan disinyalir hal ini karena kebiasaan guru yang cenderung minum teh dan kopi saat waktu istirahat. Mereka jarang membawa air bening ke kelas saat mereka mengajar di kelas (Huriawati, Yuhanna, \& Mayasari, 2016).

Untuk massa otot dan rating fisik, sangat memprihatinkan sekali. Ke-20 orang guru masuk dalam kategori obesitas dan kegemukan. Tidak ada satupun guru yang sehat dan bugar, sementara pekerjaan guru menuntut fisik yang fit dan bugar.

Saat wawancara, mereka memang jarang berolahraga, dan melakukan kegiatan fisik. Mudah lelah dan cenderung ingin tidur merupakan indikasi mereka mengalami diabetes (Utami et al., 2017).

Apabila diperhatikan, kebutuhan kalori setiap guru sebenarnya sudah masuk dalam kategori wajar. Namun, kurangnya informasi mengenai kebutuhan kalori yang dibutuhkan guru ini tidak mempunyai pedoman dan panduan seberapa besar kalori yang dibutuhkan tubuh masing-masing (Jati, 2014).

Dengan kelebihan berat badan tersebut, maka dapat dikatakan usia metabolisme guru-guru rata-rata 5 sampai 15 tahun lebih tua dari umur seharusnya. Hal ini merupakan indikasi tidak sehatnya guru-guru di Bangkinang. Beberapa guru banyak mengungkapkan riwayat penyakit yang sudah mereka dapatkan, dan hal ini masih terus mereka alami saat penelitian ini dilakukan.

Saat penelitian ini terungkap bahwa semua guru memiliki massa tulang yang kurang dari seharusnya. Hal tersebut ternyata bukan dikarenakan mereka jarang meminum susu untuk tulang, namun penyajiaannya yang salah saat konsumsi susu. Susu yang seharusnya disajikan dingin, malah disajikan panas (Swarinastiti, Hardaningsih, \& Pratiwi, 2018).

Hal terakhir yang paling bahaya adalah lemak perut. Tidak ada satupun guru yang diteliti dalam keadaan sehat secara komposisi tubuh. Mereka memiliki lemak perut diatas 8, dan ini termasuk bahaya dan beresiko tinggi terkena penyakit-penyakit degeneratif (Sofa, 2018).

Setelah dilakukan pengecekan awal, berikutnya peneliti memberi pemahaman dan edukasi tentang hidup sehat. Kemudian membangun kesepahaman bersama-sama guru untuk mengikuti pola dan perlakuan yang disarankan peneliti dalam penelitian ini.

Perlakukan yang peneliti lakukan yaitu pemberian asupan nutrisi shake kacang kedelai 
1121 Pengaruh Asupan Nutrisi Shake Kacang Kedelai terhadap Skala Lemak Perut Guru-guru Sekolah Dasar di Bangkinang Kota Kabupaten Kampar - Ramdhan Witarsa, Fadhilaturrahmi, Muhammad Syahrul Rizal

DOI: https://doi.org/10.31004/basicedu.v4i4.506

kepada guru-guru SD selama satu bulan dengan jam konsumsi pada sarapan antara pukul $07.00-$ 09.00. Pada jam istirahat, pukul 09.30, guru-guru mengkonsumsi buah-buahan dan sayuran. Mereka hanya makan siang lauknya saja saat jam makan siang. Siang menjelang sore hari, mereka melaporkan menu yang dimakan melalui aplikasi whatssapp ke peneliti. Pada malam harinya, mereka mengkonsumsi asupan shake kacang kedelai yang sama seperti yang mereka konsumsi saat sarapan (Leviana \& Paramita, 2017).
Perlakuan setelah satu bulan ini kemudian peneliti melakukan penimbangan kembali menggunakan timbangan yang sama seperti sebelum perlakuan, yaitu menggunakan timbangan Tanita dapat dilihat pada Tabel 9.

Komposisi Tubuh Guru-guru SD setelah diberi perlakuan, perbandingan tinggi badan dan berat badan yang dimiliki setiap guru sudah tampak jelas bahwa hampir semua guru memiliki komposisi tinggi badan dan berat badan yang mulai tampak ideal.

Tabel 9. Komposisi Tubuh Guru-guru SD sesudah Perlakuan

\begin{tabular}{|c|c|c|c|c|c|c|c|c|c|c|}
\hline No. & Kode Guru & 1 & 2 & 3 & 4 & 5 & 6 & 7 & 8 & 9 \\
\hline 1 & G1 & 70 & 25 & 50 & 34 & 5 & 1400 & 50 & 2,5 & 5 \\
\hline 2 & G2 & 73 & 26 & 51 & 37 & 5 & 1276 & 55 & 2,9 & 5 \\
\hline 3 & G3 & 70 & 27 & 52 & 35 & 5 & 1346 & 50 & 2,8 & 5 \\
\hline 4 & G4 & 78 & 27 & 50 & 35 & 5 & 1443 & 50 & 2,7 & 5 \\
\hline 5 & G5 & 70 & 25 & 50 & 35 & 5 & 1447 & 48 & 2,8 & 5 \\
\hline 6 & G6 & 70 & 26 & 50 & 35 & 5 & 1446 & 55 & 2,2 & 5 \\
\hline 7 & G7 & 71 & 26 & 50 & 34 & 5 & 1110 & 50 & 2,3 & 5 \\
\hline 8 & G8 & 68 & 27 & 50 & 34 & 5 & 1265 & 50 & 2,6 & 5 \\
\hline 9 & G9 & 70 & 25 & 51 & 34 & 5 & 1256 & 50 & 2,7 & 5 \\
\hline 10 & G10 & 70 & 25 & 51 & 34 & 5 & 1367 & 62 & 2,2 & 5 \\
\hline 11 & G11 & 70 & 25 & 52 & 37 & 5 & 1567 & 63 & 2,5 & 5 \\
\hline 12 & G12 & 78 & 25 & 50 & 35 & 5 & 1492 & 58 & 2,6 & 5 \\
\hline 13 & G13 & 70 & 26 & 50 & 36 & 5 & 1246 & 62 & 2,7 & 5 \\
\hline 14 & G14 & 70 & 26 & 51 & 36 & 5 & 1289 & 61 & 2,8 & 5 \\
\hline 15 & G15 & 80 & 26 & 51 & 34 & 5 & 1231 & 63 & 2,5 & 5 \\
\hline 16 & G16 & 77 & 27 & 50 & 34 & 5 & 1222 & 45 & 2,6 & 5 \\
\hline 17 & G17 & 78 & 30 & 49 & 34 & 4 & 1346 & 56 & 2,6 & 9 \\
\hline 18 & G18 & 80 & 30 & 49 & 34 & 4 & 1443 & 57 & 2,7 & 9 \\
\hline 19 & G19 & 73 & 30 & 48 & 33 & 4 & 1447 & 54 & 2,8 & 9 \\
\hline 20 & G20 & 75 & 30 & 49 & 33 & 4 & 1446 & 59 & 2,2 & 8 \\
\hline
\end{tabular}

Keterangan:

1. Berat badan

2. Lemak tubuh
3. Kadar air

4. Massa otot
5. Rating fisik

6. Kalori
7.. Usia sel

8. Massa tulang

9. Lemak perut

Dari 20 orang guru SD yang diteliti, terdapat 16 orang guru (G1-G16) yang mengalami penurunan berat badan rata-rata $5-10 \mathrm{~kg}$ per bulan.
Rata-rata mereka yang berhasil memiliki kebiasaan baru untuk sarapan dengan jumlah kalori yang sesuai. Penurunan berat badan ini tentu saja 
1122 Pengaruh Asupan Nutrisi Shake Kacang Kedelai terhadap Skala Lemak Perut Guru-guru Sekolah Dasar di Bangkinang Kota Kabupaten Kampar - Ramdhan Witarsa, Fadhilaturrahmi, Muhammad Syahrul Rizal

DOI: https://doi.org/10.31004/basicedu.v4i4.506

relevan dengan lemak tubuh yang dimiliki guru. Ke-16 orang guru (G1-G16) yang berhasil memiliki lemak tubuh dibawah 30\%. Hal ini menunjukkan betapa signifikannya asupan nutrisi shake kacang kedelai yang diberikan dan perubahan pola makan yang diikuti secara disiplin oleh guru-guru. Hal ini juga sesuai dengan hasil penelitian tentang pengaruh pemberian ektrak kacang terhadap kadar kolesterol total pada wanita (Sulistyaningsih \& Mulyati, 2015).

Berdasarkan tabel tersebut dapat dilihat juga kadar air yang dimiliki setiap guru. 16 guru yang berhasil sekarang memiliki kadar air yang seharusnya (diatas 50\%). Ke-16 orang guru tersebut sekarang memiliki kebiasaan baru untuk mengurangi asupan teh dan kopi, dan diganti dengan air bening hangat. Kebiasaan tersebut bukan hanya saat istirahat, namun mereka mulai bawa ke kelas saat mereka mengajar. Berbekal botol isi ulang 1 liter, mereka mempunyai kebiasaan minum air bening lebih banyak dari sebelumnya.

Untuk massa otot dan rating fisik, sangat membanggakan sekali. 16 orang guru masuk dalam kategori normal sekarang. Terdapat 16 orang guru yang sehat dan bugar dari 20 orang guru yang diteliti. Saat wawancara, mereka sekarang memiliki kebiasaan baru, yaitu berjalan kaki 30 menit setiap selesai shalat subuh. Awalnya menurut mereka sulit, namun setelah 10 hari pertama, mereka merasakan kesehatan yang jauh lebih prima dari sebelumnya, dan kebiasaan tersebut terus mereka lakukan selama penelitian ini berlangsung. Mereka yang sebelumnya kadar gula darahnya tinggi, menjadi normal. Hasil penelitian ini sejalan dengan hasil penelitian mengenai latihan yoga sebagai olahraga ringan terhadap berat badan, persen lemak tubuh, dan lingkar perut pada wanita dewasa yang kelebihan berat badan (Fatimah et al., 2018).

Melalui timbangan Tanita, guru-guru sudah mulai paham tentang kalori yang dibutuhkan tubuh. Mereka saat ini mulai proaktif dalam memperhatikan asupan kalori pada makanan yang akan mereka makan. Mereka lebih peduli dengan kesehatannya mereka saat ini. Ini hal yang membanggakan dan ternyata dengan berat badan berkurang berpengaruh terhadap kesehatan kulit mereka, hal ini sesuai dengan hasil penelitian mengenai penuaan kulit dan perawatan kulit pada usia lanjut (Damayanti, 2017).

Dengan penurunan berat badan yang dialami oleh 16 guru tersebut, maka dapat dikatakan usia metabolisme sudah menyesuaikan dengan umur seharusnya. Hal ini merupakan indikasi semakin sehatnya guru-guru di Bangkinang melalui asupan shake kacang kedelai. Beberapa guru banyak mengungkapkan riwayat penyakit yang sudah mereka dapatkan menjadi berkurang dan guru-guru merasa jauh lebih sehat, dan mereka berkomitmen untuk tetap memperhatikan asupan kalorinya setelah penelitian ini dilakukan. Mereka percaya dan menyakini bahwa asupan protein kacang kedelai bisa menyehatkan mereka, hal ini sesuai dengan hasil penelitian mengenai hubungan konsumsi protein kedelai serta konsumsi serat makanan dengan penurunan kadar kolesterol total 
1123 Pengaruh Asupan Nutrisi Shake Kacang Kedelai terhadap Skala Lemak Perut Guru-guru Sekolah Dasar di Bangkinang Kota Kabupaten Kampar - Ramdhan Witarsa, Fadhilaturrahmi, Muhammad Syahrul Rizal

DOI: https://doi.org/10.31004/basicedu.v4i4.506

pada pasien di Bandar Lampung (Safitri, Tjiptaningrum, Angraini, \& Ayu, 2016).

Ke 16 guru saat ini memiliki kebiasaan baru terkait penyajian susunya. Yang semula mengkonsumsi susu dalam keadaan panas, sekarang mereka mengkonsumsi dalam keadaan dingin. Hal ini dibuktikan dengan hasil pengecekan massa tulang mereka meningkat signifikan.

Hal terakhir yang paling membanggakan adalah hasil skala lemak perut dari ke 16 guru yang berhasil. Ke 16 guru saat ini memiliki skala lemak perut 5, dan artinya sehat. Mereka yang sudah sakit sebelumnya mulai berangsur pulih dengan penerapan asupan nutrisi shake kacang kedelai dan perubahan pola makan yang dilakukan. Hanya 4 orang guru yang tidak berhasil (G17-G20) dikarenakan faktor ketidakdisiplinan dalam melakukan pola makan sehat yang diberikan peneliti.

\section{SIMPULAN}

Simpulan yang bisa diambil dari penelitian ini adalah pemberian asupan shake kacang kedelai terhadap skala lemak perut guru-guru SD di Bangkinang Kota, Kabupaten Kampar secara signifikan dapat menurunkan skala lemak perut guru-guru SD di Bangkinang Kota, Kabupaten Kampar dari skala lemak perut bahaya ke skala lemak perut tinggi sebesar 80\% (16 guru SD). Kebaruan penelitian yang didapatkan pada penelitian ini adalah adanya peningkatan skala kesehatan guru-guru serta cara dan gaya hidup sehat. Dampak dan impak dari hasil penelitian ini adalah cara dan gaya hidup sehat yang dijalanin selama program dilanjutkan oleh guru-guru tersebut di lingkungan kelas dan lingkungan keluarganya.

\section{UCAPAN TERIMA KASIH}

Terimakasih kepada Pengelola Jurnal Basicedu yang telah membantu kami dapat mempublikasikan artikel ilmiah kami ini, dan terimakasih kami ucapkan kepada tim reviewer artikel yang telah memberikan masukan atas artikel kami ini.

\section{DAFTAR PUSTAKA}

Amanto, B. S., Siswanti, S., \& Atmaja, A. (2015). Kinetika Pengeringan Temu Giring menggunakan Cabinet Dryer dengan Perlakuan Pendahuluan Blanching. Jurnal Teknologi Hasil Pertanian, 8(2), 107. https://doi.org/10.20961/jthp.v0i0.12900

Damayanti. (2017). Penuaan Kulit dan Perawatan Kulit Dasar pada Usia Lanjut. Departemen/Staf Medik Fungsional Ilmu Kesehatan Kulit Dan Kelamin Fakultas Kedokteran Universitas Airlangga/Rumah Sakit Umum Daerah Dr. Soetomo Surabaya, 29, 73-80.

Fatimah, P. N., Dieny, F. F., Murbawani, E. A., Fahmy, A., \& Tsani, A. (2018). Latihan Yoga terhadap Berat Badan, Persen Lemak Tubuh, dan Lingkar Perut pada Wanita Dewasa. 14(4), 131-139.

Huriawati, F., Yuhanna, W. L., \& Mayasari, T. (2016). Pengaruh Metode Pengeringan terhadap Kualitas Serbuk Seresah dari Pantai Tawang Pacitan. Bioeksperimen: Jurnal Penelitian Biologi, 2(1), 35 https://doi.org/10.23917/bioeksperimen.v2i1. 1579

Jati, L. (2014). Perbedaan Asupan Lemak, Lingkar 
1124 Pengaruh Asupan Nutrisi Shake Kacang Kedelai terhadap Skala Lemak Perut Guru-guru Sekolah Dasar di Bangkinang Kota Kabupaten Kampar - Ramdhan Witarsa, Fadhilaturrahmi, Muhammad Syahrul Rizal

DOI: https://doi.org/10.31004/basicedu.v4i4.506

Pinggang dan Persentase Lemak Tubuh pada Wanita Dislipidemia dan Non Dislipidemia. Jurnal Kesehatan Masyarakat (e-Journal), 2(5), 292-299.

Krisnawati, A. (2017). Soybean as Source of Functional Food. Iptek Tanaman Pangan, 12(1), 57-65.

Leviana, W., \& Paramita, V. (2017). Pengaruh Suhu terhadap Kadar Air dan Aktivitas Air dalam Bahan pada Kunyit dengan Alat Pengering Electrical Oven. Metana, 13(2), 37.

https://doi.org/10.14710/metana.v13i2.18012

Prasetyo, T. F., Isdiana, A. F., \& Sujadi, H. (2019). Implementasi Alat Pendeteksi Kadar Air pada Bahan Pangan Berbasis Internet Of Things. SMARTICS Journal, 5(2), 81-96. https://doi.org/10.21067/smartics.v5i2.3700

Rahardjo, Bahar, \& Adi. (2019). Pengaruh Kombinasi Kacang Kedelai (Glycine Max) dan Kacang Tunggak (Vigna Unguiculata (L) Walp.) yang Diperkaya Biji Nangka (Artocarpus Heterophyllus) terhadap Daya Terima dan Kadar Protein Snack Bar. Amerta Nutrition, 3(1), 71-77. https://doi.org/10.2473/amnt.v3i1.2019.71-77

Safitri, S., Tjiptaningrum, A., Angraini, D. I., \& Ayu, P. R. (2016). Hubungan Konsumsi Protein Kedelai serta Konsumsi Serat Makanan dengan Kadar Kolesterol Total pada Pasien Puskesmas Kedaton Bandar Lampung. J Agromedicie Unila, 4(2), 301307.

Sofa, I. M. (2018). Kejadian Obesitas , Obesitas Sentral, dan Kelebihan Lemak Viseral pada Lansia Wanita. Amerta Nutr, 228-236. https://doi.org/10.20473/amnt.v2.i3.2018.228 $-236$

Sulistyaningsih, I. W., \& Mulyati, T. (2015). Pengaruh Pemberian Ekstrak Kacang Hijau terhadap Kadar Kolesterol Total pada Wanita Hiperkolesterolemia. 3.

Swarinastiti, D., Hardaningsih, G., \& Pratiwi, R. (2018). Dominasi Asupan Protein Nabati Sebagai Faktor Risiko Stunting Anak Usia 2-
4 Tahun. Diponegoro Medical Journal (Jurnal Kedokteran Diponegoro), 7(2), 1470-1483.

Utami, N. W., Majid, T. H., \& Herawati, D. M. D. (2017). Pemberian Minuman Formula Kacang Merah, Kacang Tanah, dan Kacang Kedelai terhadap Status Gizi Ibu Hamil Kurang Energi Kronis (KEK). Jurnal Gizi Klinik Indonesia, $14(1), \quad 1$. https://doi.org/10.22146/ijcn.22424

Yuarni, D., Kadirman, \& Jamaluddin, P. (2018). Laju Perubahan Kadar Air, Kadar Protein dan Uji Organoleptik Ikan Lele Asin Menggunakan Alat Pengering Kabinet (Cabinet Dryer) dengan Suhu Terkontrol. Jurnal Pendidikan Teknologi Pertanian, 1(1), 12. https://doi.org/10.26858/jptp.v1i1.5139 